\title{
Assessing Service Quality and Customer Satisfaction in Ghana's Hotel Industry: A Case Study of Engineering Guest House - KNUST
}

\author{
Gloria Honny Asirifi ${ }^{1 *} \quad$ Elizabeth Kafui Senya (Mrs.) $)^{2}$ \\ 1.Senior Lecturer at Department of Hotel Catering and Institutional Management, School of Applied Science and \\ Arts; Accra Technical University, Ghana \\ 2.Lecturer at Department of Hotel Catering and Institutional Management, School of Applied Science and Arts; \\ Accra Technical University, Ghana
}

\begin{abstract}
Background: It has been generally observed that service quality plays a very instrumental role in customer satisfaction. This study therefore, examined the impact of service quality on customer satisfaction in Ghana's hotel industry, with Engineering Guest House (EGH) of Kwame Nkrumah University of Science and Technology (KNUST).

Methods: In pursuit of the stated objective, descriptive cross-sectional survey was adopted as the research design for this study. Data was sourced from both primary and secondary sources. Structured questionnaires which was the main research instrument was used to elicit information from the participants which comprised mainly of customers of EGH-KNUST who have been patronizing the services of the said entity over 2 years. ANOVA and t-statistics were used to test the hypothesis while regression analysis was used to analyzed the data. Results: The findings showed an $\mathrm{R}^{2}$ value of 0.762 which reveals that service quality (using the SERVQUAL components) accounted for $76.2 \%$ of the variation in customer satisfaction. The f-statistics of 32.318 reveals that the model is statistically significant at 0.05 significant level.

Conclusion: It was concluded that there was a significant relationship between service quality and customer satisfaction at EGH-KNUST, hence the guest house should continue to investigate precisely what guests want and develop innovative ways to meeting guests' expectation.
\end{abstract}

Keywords: Service quality, SERVQUAL model, customer satisfaction

DOI: $10.7176 /$ JTHS/47-05

Publication date: February $29^{\text {th }} 2020$

\section{INTRODUCTION}

It has been generally observed that service quality is an important antecedent of consumer assessments of value. Value assessments in turn have been found to be inherent in consumer satisfaction which ultimately influence behavioural intentions (Babakus \& Boller, 1992). Distinguished examples of behaviours inspired by a favourable service quality appraisal are re-purchase intentions, word of mouth recommendation, loyalty and among others. Contemporary research also suggests that the causal order of this means-end value chain that is, service qualitysatisfaction-behavioural intentions is robust across national borders and as such has utility for international marketers. In an attempt to establish a competitive advantage, marketing practitioners often seek to differentiate their service offering upon service quality. Leveraging service quality has been shown to assist in both the retention and expansion of the existing customer base (Brady \& Robertson, 2001).

According to Spreng \& Mackoy (1996) service quality and customer satisfaction are indisputably the two core concepts that are at the crux of the marketing theory and practice. In today's world of intense competition, the key to sustainable competition is delivering high quality service that will in turn result in satisfied customers (Shemwell et al., 1998). Hackl and Westlund, (2000) stated that customer satisfaction is a prerequisite for customer retention and loyalty, and obviously helps in realizing economic goals like profitability, market share, and return on investment, among others. The customer's overall satisfaction with the services of the organization is a function of all the encounters/experiences of the customers with that organization.

Analogous to service quality is customer satisfaction which also occurs at multiple levels in an organization, for example, satisfaction with the contact person, satisfaction with the core service and satisfaction with the organization as a whole. Service quality is deeply embedded in virtually every aspect of organizational life. Indeed, it is the bedrock of every organization in the sense that it encompasses the organization's culture, the assumptions of its employees, and all that is taken for granted about the way people should think and act in the organization. Service quality plays a pivotal role in the success of a hotel businesses and this role cannot be repudiated. It is therefore paramount for the hotel managers to thoroughly understand what exactly customers want. Pinpointing the specific expectations of customers, the dimensions of the service quality, and their relative importance for customers for each specific segment of hotel industry would definitely help managers in the challenge of improving the service quality of their organization. According to the work of Gundersen et al. 
(1996) service quality tends to be more stable over time and when other constitutents have been considered, it leads to customer loyalty and higher profitability.

It has been observed that customers are very vital as far as sustainability and development of an organization is concerned. The retention of customers is therefore important to any meaningful management. Stanley Brown (1999) emphasized that management should realize that it is more cumbersome in acquiring new customers as compared to the cost of keeping that customer. Correspondingly, the focus of management must therefore centre on maintaining customers and winning more.

Customer Care is an essential component in the organizational framework of Engineering Guest House at KNUST. Nonetheless, there is still room for innovation and improvement to meet the satisfaction of customers who are quite dynamic and enigmatic with ever changing needs.

Despite the fact that Engineering Guest House is a major stakeholder in the Ghanaian hotel industry, it appears its customer care is characterized with challenges and difficulties which militate against its operations and attraction of customers. For instance, it is not uncommon to hear customers complain of delays in food service. Many at times, customers have to wait for longer period of time before being attended to by a porter especially when they need some assistance in their room. This has caused a lot of dissatisfaction among some customers and has affected their perception of the Guest House's customer care and focus. More importantly, this has led to some attrition which is of dire consequences to the future of the Guest House.

This research therefore aims to assess ways of improving customer care in Engineering Guest HouseKNUST by thoroughly investigating quality of service provided by the entity and ultimately suggest ways to improving customer care which will tend lead to customer retention.

\subsection{Objectives of the Study}

Quality service has become the most vital successful factor for a hotel to either sustain gains made or move to the next level of efficiency and improve and enhance its operations, particularly in case of Engineering Guest House From the background the questions that are worth answering in this study are: how is service delivery rendered in the hotel industry and what are the ways of improving quality service delivery in the hotel industry. To provide answers to the aforesaid research questions, objectives have been developed to guide the study. The main objective of this study is to assess ways of improving customer care in the Ghanaian hotel Industry with reference to Engineering Guest House-KNUST.

In pursuit of the general objectives, three-pronged specific objectives have outlined. These are;

1) To identify the key determinants of service quality at Engineering Guest House-KNUST using the SERVQUAL model.

2) To use SERVQUAL to determine the quality of service at KNUST Engineering Guest House- KNUST.

3) To determine the main service attributes which are essential to guests in Engineering Guest HouseKNUST.

\subsection{Significance of the Study}

The findings of the study will help the hotel industry to put in place measures that will enhance customer care, thereby ensuring customer retention. It will enable the Engineering Guest House to know the needs of its customers and find ways of meeting them to ensure loyalty and profitability. Furthermore, it will help managers of hotels to come out with services that will meet the needs and expectations of their guests. This means that the hotel industry in Ghana will be equipped with a lot of customer care strategies and tailor made services which will attract more customers.

This study will add to the existing literature and documents already available on improving customer care. Moreover, the Ghana Tourist Board, the governing body of hotels in Ghana, will be guided by the findings in the formulation and implementation of policies and the star rating of the hotels and guests houses in Kumasi and the country as a whole.

\section{LITERATURE REVIEW}

\subsection{Service Quality}

2.1.1 Definition of service quality and components of service quality.

Several definitions of service quality exist in the literature. Firstly, Taylor \& Baker (1994) defined service quality as "a number of inter-related factors including the way in which individuals are treated by providers, the scope of services and contraceptives available to clients, the quality of the information provided to the clients and quality of the counseling skills, the promotion of individual choice, the technical competence of providers, and the accessibility and continuity of services".

Again, Taylor and Baker studied the relationship between service quality and customer satisfaction. In this study service quality was defined as "the consumer's overall impression of relative inferiority superiority of the organization and its services” (Taylor \& Baker, 1994, p.167). 
In her literary works, Santos (2003) focuses on service quality in electronic commerce and she defines service quality as "the overall evaluation of a specific service firm that results from comparing that firm's performance with the customer's general expectations of how firms in that industry should perform" (p.236).

It has been generally acknowledged that service quality is the major impetus for business sustainability and in today's competitive business environment, it is acknowledged that high quality service is an important ingredient for business success (Carlzon 1987; Rust \& Oliver 1994). Furthermore, service quality has become the yardstick for assessing how well service level matches with customer expectations. The main thrust of the study of service quality is the customer gap, that is the difference between customers' expectations and perceptions of the service received. Expectations are the reference point customers have before entering and experiencing the service of a particular hospitality establishment whereas perceptions reflect their experience of the service that they have actually received. Therefore, it is the duty of hotels to strive to close or narrow this gap, that is, between what is expected and what is received, to satisfy their customers and to build long-term relationships with them. (Lewis \& Boom, 1983)

\subsection{Service and Satisfaction}

The focus here is to elaborate on these twin issue - customer service and customer satisfaction as the two operates conjointly; hence, customer satisfaction cannot be achieved without effective customer service. And customer service too cannot be continually monitored, adapted and improved without the feedback from guests regarding customer's satisfaction. Therefore, the relationship between these two phenomena is bi-causal.

According to Pizam \& Holcomb (2008, p66), they posited that customer satisfaction is "the ability of an organisation to fulfil the needs of its customers". Hence, customer service is the delivery of quality service to meet the customers' needs or expectations; and these needs can be intangible as well as tangible.

In the hospitality space, and especially the hotel industry, service quality is a fundamental element of the guest experience. Again, Jeong \& Oh (1998), observed the importance of service quality by stressing that the hospitality industry is very fiercely competitive and the competition is mostly geared towards acquiring more customers and the only conduit to achieving the aforesaid is through customer satisfaction. This is simply because customer retention through service quality is very crucial.

It is therefore important to note that service quality is not about meeting the expectations of customers but rather it is about exceeding their expectations.) Hotels over the years have fueled customers' higher quality expectations by using service quality as a marketing tool. To this end, hotels have not other choice than to continually improve customer service to meet the demands of the ever discerning and knowledgeable customers (Jones \& Lockwood 2004)

\subsection{Theoretical and Conceptual Framework}

A conceptual framework provides a broad and pictorial understanding of the phenomena of interest, the assumptions and the philosophical views of the study (Polit and Beck, 2004). The main focus of this study is to examine service quality and its impact on customer satisfaction.

This study adopted the theoretical framework propounded by Parasuramanet al. (1988) but further augmented and developed by Juwaheer (2004). Juwaheer (2004) model on SERVQUAl was adopted because its components touched on all the element of service that is rendered by a hotel. Therefore, the theoretical framework for the research is that the service quality in the hotel industry is the independent variable and the customer satisfaction is the dependent variable. The independent variable is the SERVQUAL components tangibility, reliability, assurance, responsiveness and empathy impact on customer satisfaction in the hotel industry. 


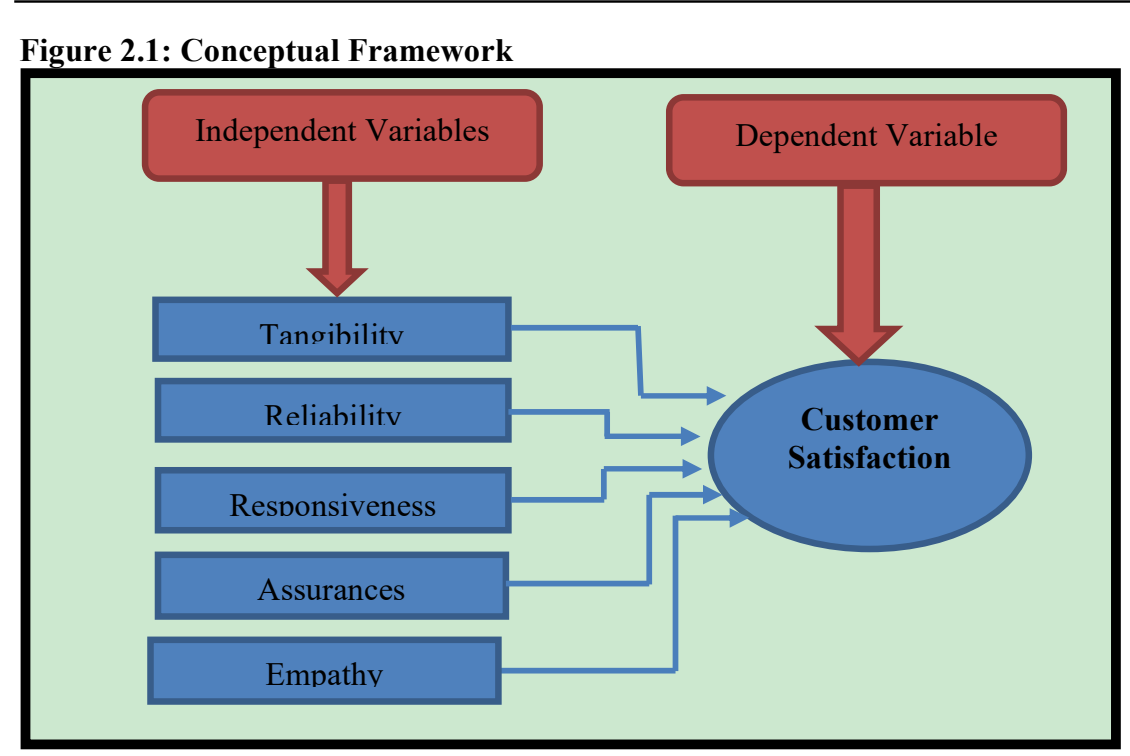

\section{RESEARCH METHODS}

\subsection{Research Design}

The study employed a descriptive cross-sectional survey to gain insight into the concept of service quality and customer satisfaction in Engineering Guest House - KNUST (EGH-KNUST). Descriptive research also known as statistical research was used to describe the characteristics of objects, people, groups, organisations or environments. In their research book, Zikmund, Babin, Carr \& Griffin (2013) asserted that descriptive research design helps to address who, what, when, where, why and how questions; and that, descriptive studies are conducted with a considerable understanding of the situation being studied. Descriptive research design is adopted in this study simply because the researcher is interested in determining and describing the various component of service in a hotel that influence guests' satisfaction. Under the descriptive research design, quantitative approach was used to estimate and establish the key determinants of service quality and the various service attributes that are paramount to guests in EGH-KNUST

\subsection{Population And Sample Size}

Population here refers to the "universe of units from which the sample is to be selected" (Ofori \& Dampson, 2011). The population comprised of about 400 customers that patronize the services of EGH-KNUST on daily basis. Conveniently, purposive and quota sampling techniques were used to draw the sample size for the study. Under the purposive sampling approach, the respondents were selected due their long association or patronage of EGH-KNUST services for not less than two years. Quota sampling was adopted in selecting specific number of respondents in different departments of EGH-KNUST. This was done in order to get fair representation of respondents from all the departments. To obtain acceptable levels of confidence and accuracy, a total sample size of 100 were selected which consisted of 50 guests to the restaurant, 30 guests to the bar, and 20 guests to the rooms. The number of respondents sampled was as a result of the number of Guests who visit the EGH-KNUST within a week. The table below shows the number of respondents sampled in relation to the number of Guests that visited the EGH-KNUST.

\section{Sampling table}

\begin{tabular}{|l|l|l|l|}
\hline SECTIONS & Target Population & Sample Size & Percentage (\%) \\
\hline Restaurant & 140 & 70 & $50 \%$ \\
\hline Bar & 20 & 10 & $50 \%$ \\
\hline Accommodation & 40 & 20 & $50 \%$ \\
\hline TOTAL & $\mathbf{2 0 0}$ & $\mathbf{1 0 0}$ & $\mathbf{5 0 \%}$ \\
\hline
\end{tabular}

\subsection{Data Sources And Analysis}

Primary data was obtained from the respondents via questionnaires which was the main research instrument. The questions in the questionnaire were structured in a manner that helped the researchers meet the research objectives. In addition, questions relating service quality were presented in a Likert style rating scale in which the participants were asked to rate the service components provided by EGH-KNUST. Secondary data was however gathered from relevant academic journals, books, articles among others. 
Primary information gathered were analysed using SPSS version 20, after the filled questionnaires were cleaned and collated. Out of the 100 questionnaires that were distributed, it was 98 questionnaires that were retrieved and deemed appropriate for the analysis. Hence the analysis in this study was based on the responses provided by 98 respondents.

\subsection{Research Hypothesis}

1. $\mathrm{H}_{\mathrm{O}}-$ There is no significant relationship between service quality and customer satisfaction $\mathrm{H}_{1}$ - There is significant relationship between service quality and customer satisfaction.

2. $\mathrm{H}_{\mathrm{O}}-$ There is negative relationship between service quality and customer satisfaction $\mathrm{H}_{1}-$ There is positive relationship between service quality and customer satisfaction.

\section{RESULTS AND DISCUSSION}

\subsection{Socio-Demographic Characteristics of The Respondents}

The biographic data of the participants touched on their gender, age and the years of association (i.e. the number of years they have been patronizing the services of EGH-KNUST). More than half $68(69.4 \%)$ of the respondents were males and the rest $30(30.6 \%)$ were females. Majority of the respondents are within the ages of 31-50yrs. In addition, $83(84.7 \%)$ of the respondents have been patronizing the services of EGH-KNUST for about 2-4yrs. Amongst these demographic characteristics, the respondents' years of association with EGH-KNUST was statistically more significant $(\mathrm{t}=52.077, \mathrm{~N}=98, \mathrm{SD}=0.039, \mathrm{p}=0.00)$ compared to gender and age. This can be observed in table 4.1.2.

Table 4.1.1. One-Sample Statistics

\begin{tabular}{|l|r|r|r|r|}
\hline & \multicolumn{1}{|c|}{$\mathrm{N}$} & \multicolumn{1}{|c|}{ Mean } & Std. Deviation & \multicolumn{1}{c|}{ Std. Error Mean } \\
\hline Gender & 98 & 1.31 & .463 & .047 \\
Age & 98 & 2.83 & 1.184 & .120 \\
Association with EGH-KNUST & 98 & 2.05 & .390 & .039 \\
\hline
\end{tabular}

Table 4.2: One-Sample Test

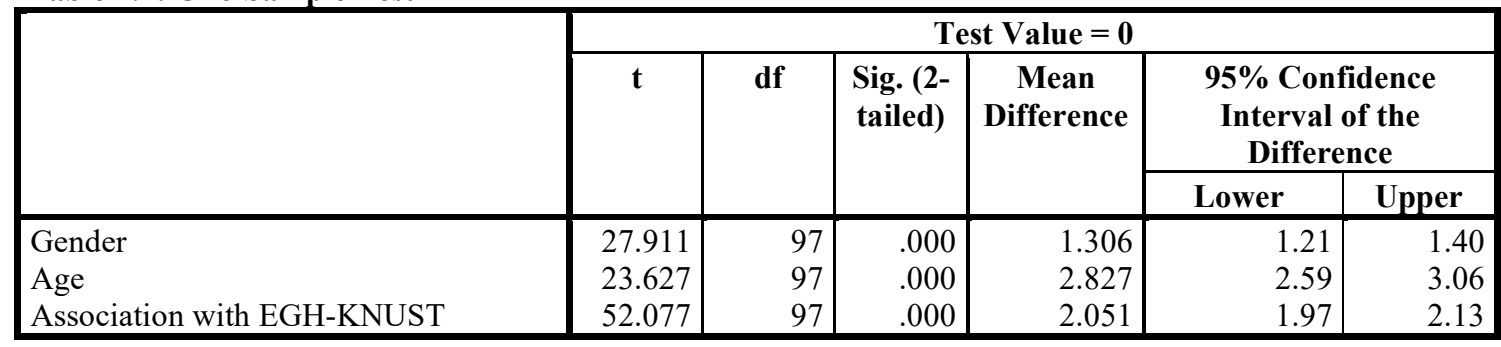

\subsection{Main Findings.}

As stated earlier, the study adopted SERVQUAL with components such as tangibility, reliability, responsiveness, assurance and empathy in assessing the impact of service quality on customer satisfaction. Various indicators were used to explain the key components of SERVQUAL, for instance, some of the availability of modern equipment, employees' appearance, the physical appearance of EGH and the availability of requisite materials for service delivery. However, the before the analysis, a reliability test on the independent variables (SERVQUAL components) revealed that the Cronbach's alpha for the variables is 0.991 which is higher than the minimum value of 0.70 which denotes stability of data. This indicated in table 4.2.1

Table: 4.2.1 Reliability Statistics

\begin{tabular}{|r|r|r|}
\hline Cronbach's Alpha & Cronbach's Alpha Based on Standardized Items & N of Items \\
\hline .991 & .992 & 20 \\
\hline
\end{tabular}


4.3 The impact of service quality on customer satisfaction.

Table 4.2.2 One-Sample Statistics

\begin{tabular}{|l|r|r|r|r|r|r|r|}
\hline SERVQUAL Components (Indicator variables) & Mode & Mean & t & df & $\begin{array}{c}\text { Sig. } \\
\text { (2- } \\
\text { tailed) }\end{array}$ & $\begin{array}{c}\text { Std. } \\
\text { Deviation }\end{array}$ & $\begin{array}{c}\text { Std. } \\
\text { Error } \\
\text { Mean }\end{array}$ \\
\hline Tangibility 1 - Modern Equipment & 4 & 3.84 & 64.739 & 97 & .000 & .587 & .059 \\
Tangibility 2 - Employees Appearance excellent & 4 & 3.98 & 45.740 & 97 & .000 & .861 & .087 \\
Tangibility 3 - EGH Physical Apprearance good & 4 & 3.98 & 58.521 & 97 & .000 & .673 & .068 \\
Tangibility 4 - Materials for service delivery & 4 & 3.68 & 43.814 & 97 & .000 & .832 & .084 \\
Reliability 1 - Fulfilling promises & 4 & 3.87 & 53.715 & 97 & .000 & .713 & .072 \\
Reliability 2 - Prompt service delivery & 4 & 3.76 & 37.738 & 97 & .000 & .985 & .100 \\
Reliability 3 - Interest in client's problem & 4 & 3.94 & 52.438 & 97 & .000 & .744 & .075 \\
Reliability 4 - Delivery promise on time & 4 & 3.63 & 34.276 & 97 & .000 & 1.049 & .106 \\
Responsiveness 1 - Error free records & 4 & 3.69 & 46.182 & 97 & .000 & .792 & .080 \\
Responsiveness 2 - Timely completion of bills & 4 & 3.76 & 45.024 & 97 & .000 & .826 & .083 \\
Responsiveness 3 - Prompt service & 4 & 3.84 & 38.709 & 97 & .000 & .981 & .099 \\
Responsiveness 4 - Willingness to help clients & 4 & 4.04 & 54.720 & 97 & .000 & .731 & .074 \\
Responsiveness 5 - Prompt response to clients & 4 & 3.82 & 40.917 & 97 & .000 & .923 & .093 \\
request & 4 & 4.19 & 51.387 & 97 & .000 & .808 & .082 \\
Assurances 1 - Safety in transaction & 4 & 3.96 & 48.314 & 97 & .000 & .811 & .082 \\
Assurances 2 - The behaviour of employees & 4 & 4.14 & 47.603 & 97 & .000 & .862 & .087 \\
Assurances 3 - Technical know-how & 4 & 4.20 & 52.953 & 97 & .000 & .786 & .079 \\
Assurances 4 - Courtesy & 4 & 4.02 & 49.798 & 97 & .000 & .799 & .081 \\
\hline Empathy 1 - Convenience & 4 & 4.08 & 50.000 & 97 & .000 & .808 & .082 \\
\hline Empathy 2 - Customer's priority & 4 & 3.90 & 45.759 & 97 & .000 & .843 & .085 \\
\hline Empathy 3 - Special needs of client & & & &
\end{tabular}

Source: Researcher's Computation, 2018

A Likert scale ranging from 1 to 5, in an ascending order (i.e. from Strongly Disagree, Disagree, Neutral, Agree, and Strongly Agree) was used to assess the indicator variables. From table 444, the modal value is 4 for all the SERVQUAL components, this basically means that most of the respondents agreed to all the positive declarations on the services provided at EGH-KNUST. The minimum mean value is 3.68, approximately the mean value for the indicator variables is 4 which is equal to the modal mark. Conclusively, all the respondents agreed to the various declarations. Further statistical analysis also reveals a positive t-statistics for all the SERVQUAL components which are significant at 95\% confidence interval. In addition, $14.3 \%$ of the respondents deemed the service delivery of EGH-KNUST as extremely good while $45.9 \%$ said the EGH service delivery is good. It was only $8.2 \%$ of the respondent who said their service is poor, the remnant $31.6 \%$ did not give any remarks.

Accordingly, tangibility aspect of the SERVQUAL at EGH-KNUST uncovered that, EGH has modern equipment to enhance the quality of service they provide to guests, the appearance of employees is excellent, physical appearance of EGH is great and exquisite, and the various materials used in service delivery are superb. Under reliability, the results exemplify that EGH fulfil any form of promise they make to the consuming public, they provide prompt service, they are interested in client's problem/entreaties and they deliver on their promise on time.

\section{Test of Hypothesis}

Hypothesis 1:

$\mathrm{H}_{\mathrm{O}}$ - There is no significant relationship between service quality and customer satisfaction

$\mathrm{H}_{1}$ - There is significant relationship between service quality and customer satisfaction.

Table 4.2.3 ANOVA

\begin{tabular}{|c|c|c|c|c|c|}
\hline Model & Sum of Squares & df & Mean Square & $\mathbf{F}$ & Sig. \\
\hline Regression & 6.841 & 20 & .342 & 32.318 & $.000^{\mathrm{b}}$ \\
\hline Residual & 2.138 & 77 & .028 & & \\
\hline Total & 8.980 & 97 & & & \\
\hline
\end{tabular}

a. Dependent Variable: Customer satisfaction

b. Independent Variables/Predictors: (constant), SERVQUAL components (Tangibility, Assurance, Responsiveness, Empathy and reliability) 
Table 4.2.4 Model Summary

\begin{tabular}{|l|r|r|r|r|r|}
\hline Model & $\mathrm{R}$ & R Square & Adjusted R Square & $\begin{array}{c}\text { Std. Error of the } \\
\text { Estimate }\end{array}$ & Durbin-Watson \\
\hline 1 & $.873^{\mathrm{a}}$ & .762 & .700 & .167 & 1.841 \\
\hline
\end{tabular}

Source: Researcher's Computation, 2018

From table 4.2.3 and 4.2.4, the statistical analysis reveals that there is a significant relationship between service quality and customer satisfaction. This is based on the fact that, $\mathrm{R}^{2}$ is 0.762 which signifies that the independent variables (SERVQUAL components) explain an approximately $76 \%$ of the dependent variable (customer satisfaction). In addition, the f-statistics shows the value of 32.318 at $5 \%$ significant level. The implication is that SERVQUAL components largely influence customer satisfaction hence EGH-KNUST should continue to improve on SERVQUAL components of their services in order to get the customers more satisfied which will in tend lead to customer retention. To this end, the null hypothesis is rejected, thereby accepting the alternative hypothesis which states that there is a significant relationship between service quality and customer satisfaction, this is consistent with the study Rompho (2012) who applied SERVQUAL scale to study hotels in Thailand.

\subsubsection{Hypothesis 2}

$\mathrm{H}_{\mathrm{O}}-$ There is negative relationship between service quality and customer satisfaction

$\mathrm{H}_{1}$ - There is positive relationship between service quality and customer satisfaction.

Nevertheless, the f-statistics which is 32.318 is positive hence depicting a positive relationship between service quality and customer satisfaction. Again, the t-test on each indicator variable is positive and this can be observed in table 4.2.3, therefore, the null hypothesis of the second hypothesis which posited a negative relationship between service quality and customer satisfaction is rejected.

\section{Conclusion}

Indeed, service quality is a sine qua nom in the service provision in the hospitality industry. Hence role of service quality in the success of hotel businesses cannot be denied. It is paramount for hotel managers to have a good understanding and appreciation of what exactly the customers want/need. Identifying the specific expectations of customers, the dimensions of the service quality, and their relative importance for customers for each specific segment of the hotel would definitely help managers in the challenge of improving the service quality of their hotels

Staff of Engineering Guest House pays personal attention to their guests and this has really affected the services delivery of the Guests House in a positive way. Even though most of the respondents agreed that staff put customers' priority first in their operations. It was also observed that there is still room for improvement as the saying goes, "there is nothing like a perfect thing whatever it is, it can still get better" Besides, $8 \%$ of the respondents considered the service of EGH as poor, hence the orgnaisation should endeavour to continually improve on the SERVQUAL components and simultaneously investigate the various forms service that bring utmost satisfaction to customers so that they can keep on delivery quality service.

\section{REFERENCES}

Babakus, E., Boller, G.W. (1992), "An empirical assessment of the SERVQUAL scale", Journal of Business Research, Vol. 24 pp.253-68.

Brady, M. K. \& Robertson, C. J. (2001). Searching for a consensus on the antecedent role of service quality and satisfaction: An exploratory cross national study. Journal of Business Research, 51(1), 53-60.

Gundersen, M.G., Heide, M., Olsson, U.H. (1996), "Hotel guest satisfaction among business travelers: what are the important factors?", Cornell Hotel \& Restaurant Administration Quarterly, Vol. 37 pp.72-8.

Lewis, R. C. \& Booms B. H. (1983). The marketing aspects of service quality. In L. Berry, G.

Shostack, G. Upah, (Eds.), Emerging Perspectives on Services Marketing, (pp. 99-107), Chicago: American Marketing.

Jeong, M., \& Oh, H. (1998). Quality function deployment: An extended framework for service quality and customer satisfaction in the hospitality industry. [online]. International Journal of Hospitality Management, 17 (4), 375-390. Article from Elsevier Science Direct last accessed 19th April 2011 at: www.sciencedirect.com

Juwaheer, T. D. (2004). Exploring international tourists' perceptions of hotel operations by using a modified SERVQUAL approach: A case study of Mauritius. Managing Service Quality, 14(5), 350-364.

Parasuraman, A., Zeithaml, V. A. \& Berry, L. L. (1988). SERVQUAL: A multi-item scale for measuring consumer perceptions of service quality. Journal of Retailing, 64(1), 12-40.

Pizam A. \& Ellis T. (1999). Customer satisfaction and its measurement in hospitality enterprises. International journal of contemporary hospitality management, 11(7), 326-339. 
Rust, R. T. \& Oliver, R. L. (1994). Service quality: Insights and managerial implications from the frontier. In R. T. Rust \& R. L. Oliver (Eds.), Service quality: New directions in theory and practice (pp. 1-19). Thousand Oaks, CA: Sage Publications.

Santos J., (2003). E-service quality: a model of virtual service quality dimensions. Managing Service Quality, $13(3), 233-246$.

Spreng, R. A. \& Mackoy, R. D. (1996). An empirical examination of a model of perceived service quality and satisfaction. Journal of retailing, 722, 201-214.

Taylor, S. A. \& Cronin, J. J. (1994). Modeling patient satisfaction and service quality. Journal of Health Care Marketing, 14, Spring, 34-44.

Zikmund, W. G., Babin, B. J., Carr, J. C., \& Griffin, M. (2013). Business research methods (9th ed.). New York: South-Western/Cengage Learning. 